\section{EARTH-SCULPTURE *}

III.

DO not consider it necessary to defend my facts. They are familiar enough to the geologists of this country, as displayed more or less plainly in every district of our island. I am at present concerned with the counterstatements which the Duke of Argyll would put in their place.

He states his belief that the Highland mountains have had their contour mainly given to them by "upheavals, subsidences, and lateral pressures, which have folded them and broken them into their present shapes." A belief of any kind must be founded on evidence of some sort, and that evidence must be produced if the owner of the belief desires that it should be accepted by. others besides himself. What evidence, then, does his Grace furnish as the basis on which he expects that his "belief" is to supersede what he is pleased to term "the extravagant theories of the younger glacialists"? Having shown "the antecedent improbabilities involved in the extreme theories of erosion," he states that he "proceeds to test them on the field of fact." We follow him anxiously to the field in question, and find that his so-called facts are stated in such words as these: "Loch Fyne... occupies, as I believe, the bed (sic) of an immense fault." "The transverse valley of Loch Eck lies across a steep anticlinal, and is due, in my opinion, to the extreme tension to which the crystalline rocks have been subjected." "The Pass of Awe is a rupture and chasm." These, and other similar assertions regarding various parts of the Highlands are confidently expressed, but they are accompanied by no evidence by which their accuracy may be tested. In truth, the "facts" which his Grace adduces in support of his "belief" are only other "beliefs" and "opinions" of his own. They may be correct or the reverse, but they cannot legitimately be adduced as evidence in a scientific argument. But they are very far from correct. I utterly deny, for example, the assertion that Loch Fyne lies along the bed of an immense fault, and I ask the Duke of Argyll to try to prove that it does so. Nay more, I challenge him to produce a geological section which would bear a mo. ment's examination on the ground, in which he can show the coincidence of a valley with a line of fault in any part of his own comnty of Argyll. That cases of this coincidence may be found I do not doubt, but the search for them will be useful in teaching his Grace how exceptional they are.

The Duike of Argyll does indeed offer some explanatory statements regarding some of his assertions of fact. For instance, with regard to Loch Awe, he dwells on the inclinations of the slates and the intrusion of the porphyries amone them as evidence that the present contour has becn directly the result of subterranean convulsion, and he triumphantly adduces these and similar appearances "ignored" by myself as a demonstration of the truth of his "belief." But any one who knows the Highland rocks at ail may well smile when he is told that a geologist who had cver been over the ground, even in the most cursory way, requires to have these phenomena pointed out to him. In reality I had already granted the existence of these, and far more wonderful evidences of underground movements, for I knew the Highland rocks well, and had mapped their structure over leagues of ground from the nountains of Sutherland to the moors of Forfar, and the headlands of Islay. I was therefore perfectly familiar with the paenomena to which the Duke of Argyll so confidently refers. But I had learned more about them than merely their tale of subterranean turmoil. I had found thot they did not bear directly on the origin of hill and valley at all. I had traced everywhere evidence that what

* Opening Address to the Edinburgh Geological Society, by Prof. Geikie, F.R.S. (cominued from p. $9 \mathrm{r}$ ). we now see of intruded granite or curved slate has been laid bare only after the removal of hundreds and thousands of feet of rock under which they once lay. His Grace, it would seem, has still this lesson to learn, and until he has mastered it, and, apart from any theory but simply as a matter of demonstrable fact, has realised what it involves and how vain is the attempt to connect the contorting and hardening of the rocks with the present surface features of the country, argument with him on this question seems hardly possible.

Again, I had quoted the mountain Ben Lawers, with its flanking hollow in Loch Tay, as a typical example of the kind of evidence which could be abundantly adduced from all parts of the Highlands to show the relation between geological structure and external form, and to prove from under what an enormous mass of removed rock the present surface of the Highlands has appeared. I gave a section to show at a glance the broad facts of the case-a section from which no conclusion is possible but that which I drew. But here, once more, the Duke of Argyll's belief in the all-powerful efficacy of granite and igneous rocks, or his thraldom to what he calls "the influence of a preconceived theory," brings out in well-marked prominence that obliquity of vision which prevents him from seeing anything but convulsion and fracture. He scents intrusive rocks of some sort along the south bank of Loch Tay. It would be vain to remonstrate that this alleged influence of the igneous rocks is, to say the least, as pure "inverition and imagination" as anything which the "younger school" could readily supply, or that the clenudation of that region is a momentous fact to be looked in the face and explained, not to be dismissed or denied, no matter what our "theory" or "belief" may be regarding the origin of granite. Without further ceremony, the proofs of enormous denudation at Ben Lawers and Loch Tay, together with their luckless advocate, are all bundled off with the summary judgment, so happily appropriate to its own author, "I attach no value whatever to a theory which passes over and ignores this class of facts altogether."

The dogmatic assertions which the Duke of Argyll makes regarding the influence of granite and other rocks upon the surface, and as to the existence of fractures and depressions along the line of valley and glen, are really most flagrant examples of the petitio principiz. In effect, his Grace tells us, "The "inventions and imaginations" of these younger men are based upon 'assumed facts' which 'are, in my opinion, to a large extent purely hypothetical.' I am 'suspicious of the influence which a preconceived theory has had on their estimate of evidence.' I therefore 'attach no value whatever' to their statements, and do not consider it necessary to lose time in weighing what they actually mean by this denudation of theirs, and all which, as they contend, must flow from it. My belief is that valleys are due to fractures and depressions. The Highlands abound in valleys, and therefore it must be evident to everyone capable of forming an opinion on the subject, that they abound also in proofs of fracture and depression."

In the foregoing remarks I have been dealing only with the Duke of Argyll's paper of February i 868 , which in his recent vigorously-worded address he cites as still unanswered, and which, therefore, we may suppose still to express his views. And yet no one can peruse that address without perceiving that it betokens a considerable change of opinion. Especially gratifying must it be to that "younger school" of geologists against which the Duke has so vehemently lifted up his protest, to observe that the lapse of time which he would not allow to have had much denuding effect upon the rocks, has yet been able to strip off from himselt some of that crust of preconceived "theory" against which no argument or adverse fact could once make any impression. It is true 
that his Grace formerly thought it necessary to assure us that Time could do nothing by itself, "nothing except by the aid of its great ally Force-Force working in Time." Well, we shall not quarrel about the use of words, but cheerfully admit that the change which has become perceptible in the opinions of the Duke of Argyll is wholly the result of "Force working in Time," and not a very long time, for it cannot be stretched out beyond five years. Surely if the lapse of so brief a space, with all the amount of Force which we can crowd into it, can have modified geological opinions which certainly seemed as solidly and unalterably fixed as his own Ben More itself, it can hardly be too much to hold that by the end of another lustrum still further modification may justify the confident belief that his Grace may still come to join the "younger school" heart and hand. We can assure him a jubilant welcome.

But it may be asked what is the nature of this present alteration of view? In brief, it may be put thus : the Duke of Argyll finds that, after all, denudation is one of those disagreeable facts which will insist on being prominent-" chiels that winna ding." He has discovered that it really has had some share in the shaping of the present outlines of the land. He now admits in words "that the forms of hill and valley which preceded the coming-on of glacial conditions [during the Ice age] had been themselves determined in a large degree by previous denudations." And even though this general admission is neutralised by statements which follow it, it is most welcome as an indication doubtless of the effect of those "more extended opportunities of observation" which his Grace tells us he has since enjoyed, and on the continuance of which our hopes of his secession to the ranks of the "younger school" are mainly based.

The Duke of Argyll appeals once more to the details of geological structure. Most gladly do we accede to the appeal. He points to the contorted condition of the older rocks as evidence of the extent to which they have been affected by subterranean movements. But no geologists are more familiar with these facts than his maligned "younger school." He conceives that it was after such movements that the forces of denudation began to work. Most assuredly; this has been explained over and over again. He affirms that "so long as such hills and mountains last at all, and wherever they are exposed to view, they bear upon them the unmistakeable impress of their origin and of the mighty subterranean forces to which their structure is due." This sentence is rather ambiguous. If it means that contorted rocks retain evidence of contortion, such an obvious truism was hardly worth a sentence to itself. If it means that a mountain made of contorted rocks has had its form determined at the time of contortion, the statement is mere assertion and a begging of the very question to be proved.

In the same address the noble president declares that "denudation has done its work along the lines determined by upheaval, by fracture, and by unequal subsidence." This has never been denied by anyone. A main object of my book was to show how, by means of denudation along such lines, much of the present contour of Scotland has been produced. Again we are told-"All sedimentary beds must have had an edge somewhere; and if they are lifted into a vertical position and the edges come to be exposed, the removal of a small amount of material may result in a horizontal surface, or in surfaces cutting across the lines of structure at every variety of angle." If the Duke intends this explanation to apply not to a mere hand specimen, but to any district of convoluted and vertical rocks, such as the hills of Wales or the Southern Uplands or Highlands of Scotland, he cannot have noticed the string of physical absurdities which it involves. The rocks are often vertical, or nearly so, for miles at a stretch. Could we put them into something like their original horizontal or gently inclined posi.. tion their present edges would end off in a cliff many miles high. Can his Grace expect anyone to believe that the beds, which certainly "must have had an edge somewhere," ever ended off in that fashion? But this would be only a part of the feat. In actual fact the rocks have been violently contorted, so that a series several hundreds or even thousands of feet in thickness is folded again and again upon itself. The present surface has been cut across these foldings, and in great part has its inequalities independent of them. If we could flatten these curved rocks out again from their present condition they would show a series of deep sharp troughs separated by steep pyramidal ridges of fiat strata. And from the Duke of Argyll's teaching we should learn that this wonderful arrangement was the normal plan in old times of laying down sediment which, instead of always going to the bottom and filling up the hollows as it does nowadays, contrived then to ascend, layer after layer, like the tiers of the Great Pyramid, as if it were under the impulse not of mere gravity or of the play of ocean currents, but of the methodical action of organisms like the coral polyps. We should further learn that these neatly-shaped sand and mud ridges and troughs were so accurately laid down that when subterranean forces came into action and crumpled the whole up, every ridge popped conveniently into a trough below, as if a trap-door had been opened for its reception, and with such nice adjustment as to bring its top to the same general level as the bottom of the former troughs !

The truth is, and, in common fairness I am bound frankly to state it, that such assertions as these with which I am dealing, could never be made if geological structure were really understood and kept in view. This is a matter of science, and is only to be mastered by the same patient toil which is required in other scientific inquiries. Moreover, it is by no means so easily mastered as it seems to be. The first absolute requisite for overcoming our ignorance, is to reduce our facts to the test of ocular proof and measurement. Let us construct a section across the tract of which we would master the structure, and to avoid risks of error from exaggeration of proportion, let us begin by making the section as nearly as possible on a true scale, that is, giving the same value to length as to height. With the outline of the ground accurately traced we may then, section in hand, insert upon it at the proper places, and with the true angle of dip, such rocks as we be able to see exposed. Having fixed these data in this patient way, we may expect with some confidence to understand and fill in the geological structure of the ground for ourselves, and to make it intelligible and credible to others. Until we have gone through such a training ourselves, or have learnt adequately to appreciate what it is from the labours of others, we have no right to utter an opinion on the relations between geological structure and external form, for we are destitute of one of the necessary qualifications for dealing with the problem.

The greater part of the recent address of the president of the Geological Society deals with the traces of iceaction in this country, and the manner in which they are to be accounted for. In his remarks upon this subject, the Duke again places himself in opposition to the views of the "younger school," and expresses opinions from which every member of that school would, I am sure, emphatically dissent. It is no part of my present purpose to enter upon these. I cannot, however, pass by one statement in the address. His Grace asserts that these restless "younger geologists" have recently made a most complete change of front. He therefore directs his attack against this new position. He says that they no longer maintain the existing systems of hill and valley to have been cut out of the solid by an enormous glacier, but admit the general contour of the country to have been very much the same before the Ice age as after it, all the 
work of the ice having been to deepen valleys, degrade hills a little, and fill up the plains and hollows with clay and sand. "Such as $I$ understand it," says the Duke, "is the new glacial theory." But surely he can have paid but scant attention to the subject if he imagines that this idea is in any sense new. I really cannot recall that the geologists of the "younger school " have for many years past held any other view than that which they are now said to have adopted only recently. If, for example, his Grace will turn to the little volume which he abused so heartily in the spring of 1868 , he will find the "new view" stated as plainly there as words can express it (see page 150 ). And yet in this address he thinks it needful to adduce evidence to disprove that valleys have been gouged out by an universal ice-sheet-a notion which, according to his own showing, the "younger scheol" does not hold.

These remarks have been extended this evening beyond the length to which I had originally proposed to confine them. My excuse must lie partly in what to myself is the ever tresh charm of the subject, and partly in the desire to vindicate the fair fame of the modern Huttonian school of geology from attacks which had been in some measure called forth by writings of my own. I have again to express my regres that it was impossible to avoid an appearance of personal conflict, and I am conscious that a man who does his best to give as good as he gets in such conflict is apt to do more than he meant. $I$ can only hope that this consciousness has kept me far within the bounds of legitimate reply.

Of one thing I feel securely confident. When the din of strife has ceased and men come to weigh opinions in the dispassionate light of history, the profound influence of the Huttonian doctrines of the present time on the future course of geology will be abundantly recognised. By their guidance it will be possible to reconstruct the physical geography of the continents, in successive ages back, perhaps into some of the earliest periods of geological history. This work indeed is already in part accomplished. But much more remains to be done before the history of the land on which we live has been wholly unravelled. This is the task to which we have set ourselves, in which we have found ample scope for enthusiasm and hard work, and out of which we trust that there will eventually come a story of permanent interest to all whose range of vision extends beyond the present condition of things, and who would fain understand what now is by the light of what once has been.

\section{EXTERMINATION OF IIARINE WAMMALIA}

THROUGH the kindness of a friend, there has been placed in my hands a little book-one of the few copies in England-which though not much bigger than a pamphlet, seems to me more deserving of notice than I fear it is likely to obtain. Of its author, I may say, I know nothing. Its title is "Mammalia, Recent and Extinct; an Elementary Treatise for the use of the Public Schools of New South Wales. By A. W. Scott, M.A." It is published at Sydney by Thomas Richards, Government Printer, and bears date 1873 . One's first wish on looking at it was that such a book might be wanted "for the use of the Public Schools of "the old country; but it is not my object now to enlarge on this theme or even to call attention to, or pass judgment upon it from a scientific point of view-though some of the author's opinions are, if not novel, such as have not been generally received. Mr. Scott's treatise is confined to the "Pinnata, Seals, Dugongs, Whales," \&c. and he tells us in his preface why he has so limited it:-

"Whatever information we possess upon the natural history of the finned mammals, particularly in a popular, yet scientific form, has been so scantily and unequally distributed, that in this direction a comparatively new field may be said to be open to the teacher as well as to the youthful inquirer.

"Influenced, also, by the great commercial value of several species of the pinnata, I have felt anxiously desirous to direct, without further delay, the attention, and thus possibly secure the sympathy, of readers, other than students, to the necessity of prompt legislative interference, in order to protect the oil and fur producing animals of our hemisphere against the wanton and unseasonable acts commisted by unrestrained traders; and thus not only to prevent the inevitable extermination of this valuable group, but to utilise their eminently beneficial qualities into a methodical and profitable industry.

"Keeping steadily in view these two objects, whose im. portance, I trust, will bear me out in deviating from my original intention in the order of the issue of publication, I have endeavoured ... by devoting as much space as my limits would permit to the consideration of the animals whose products are of such commercial value to man, and whose extinction would so seriously affect his interests, to point out the pressing necessity that exists for devising the means of protection for the Fur Seals and the Sperm and Right Whales of the Southern Ocean.

"To evidence what great results may be effected by considerate forethought, I refer the reader to pages 8 to I 3 of this treatise [containing extracts from the excellent paper on Otarizdce by Messrs. Allen and Bryant (Bulletin Harvard College, ii. pp. I-108)], where be will see that, under the fostering care of the United States Government, the Northern Fur Seals of commerce, which but a few years ago were nearly extinct, have already, by their rapid increase and mild disposition, developed themselves into a permanent source of national wealth.

"The islands of the Southern Seas, now lying barren and waste, are not only numerous, but admirably suited for the production and management of these valuable animals, and need only the simple regulations enforced by the American Legislature to resuscitate the present state of decay of a once remunerative trade, and to bring into full vigour another important export to the many we already possess."

Mr.Scott's design appears to me eminently praiseworthy; nnd the question it raises is, without doubt, one which must imperatively demand (and will, I trust, in time) the attention not only of the naturalist, but of everyone who is interested in the commercial prosperity of this country and its colonies. Though to some extent their place has been supplied by mineral and vegetable oils, for certain purposes it is, I believe, admitted that animal oils are absolutely required, and the demand for these oils increases with the increase of civilization. Now no one who has at all closely investigated the subject of the extermination of animals by man can come to any other conclusion than that unless, by some legislative restriction (which from the nature of the case will probably have to be international) it is prevented, all the Marine Mammalia are inevitably doomed to early extinction. Who can read of the butcheries which are yearly perpetrated on the breeding Seals of the icefloes in the North Atlantic, and as yearly recorded with more or less zest in the newspapers, without feeling certain that the same fate awaits them as has overtaken, or is overtaking, so many of their fellow-denizens of the deep ? Where is the Rhytina of Behring's Island ? Absolutely abolished from the face of the earth! Where are the Manatees that played in the waters of the Antilles, when those "isles of the sun "were first visited by Europeans? Limited to some three or four muddy creeks in as many of the larger islands! Where is the Right Whale that used to throng the Greenland seas, the Walrus that haunted the Gulf of St. Lawrence? Driven so far to the northward that ships in the pursuit of either are now led to encounter the greatest perils! Where is that smaller Whale which furnished employment for all the navies of Biscayan ports? You have to seek its remains in the museum at 